\title{
The Evaluation of the High Temperature Gas Cooled Reactor Safety to Fulfill the Requirement of the Next Generation Nuclear
}

\author{
Julwan Hendry Purba*1, Arya Adhyaksa Waskita ${ }^{1}$, D.T. Sony Tjahyani ${ }^{1}$ \\ ${ }^{1}$ Center for Nuclear Reactor Technology and Safety, National Nuclear Energy Agency of Indonesia (BATAN), Gd.80 \\ Tangerang Selatan, Indonesia, 15310
}

\begin{tabular}{l}
\hline ARTICLE INFORMATION \\
\hline Article History: \\
Received: \\
25 September 2019 \\
Received in revised form: \\
6 December 2019 \\
Approved: \\
9 December 2019 \\
\end{tabular}

Keywords:

high temperature gas cooled reactor

inherent safety features fundamental safety functions confinement functions next generation nuclear plant

\begin{abstract}
THE EVALUATION OF THE HIGH TEMPERATURE GAS COOLED REACTOR SAFETY TO FULFILL THE REQUIREMENT OF THE NEXT GENERATION NUCLEAR. High temperature gas cooled reactor (HTGR) has been considered to be the most promising option to meet energy demands in the future. It has also been selected as the next generation nuclear plant. The primary safety requirement of the next generation nuclear plant design is to limit radioactive material releases to practically eliminate the need for public evacuation or sheltering beyond the exclusion area boundary. The purpose of this study is to evaluate the safety design of HTGRs in order to fulfill the requirement of the next generation nuclear plant. To achieve this objective, inherent safety features, fundamental safety functions, and confinement functions realized into the design of HTGRs are comprehensively evaluated. It is found that design provisions of HTGRs can fulfill the intention of keeping radionuclides at their original sources. The layers of the coated fuel particles are very robust to retain nuclear fission products for all foreseeable reactivity events. There will be no possibility of radioactive materials to be released even though related safety systems and operator intervention are not involved in the recovery actions. This design has complied with the requirement of the next generation nuclear plant, which is to practically eliminate the need for public evacuation or sheltering beyond the exclusion area boundary.
\end{abstract}

\begin{abstract}
ABSTRAK
EVALUASI KESELAMATAN REAKTOR BERPENDINGIN GAS TEMPERATUR TINGGI DALAM MEMENUHI PERSYARATAN PEMBANGKIT NUKLIR MASA DEPAN. Reaktor berpendingin gas temperatur tinggi diprediksi akan menjadi pilihan yang menjanjikan untuk memenuhi kebutuhan energi masa depan. Persyaratan utama keselamatan bagi pembangkit nuklir masa depan adalah pembatasan pada lepasan material radioaktif sehingga secara praktis evakuasi dan sheltering diluar exclusion area boundary dapat dihilangkan. Tujuan penelitian ini adalah mengevaluasi desain keselamatan HTGR dalam memenuhi persyaratan pembangkit nuklir masa depan. Untuk mencapai tujuan ini maka fitur keselamatan melekat, fungsi keselamatan fundamental, dan fungsi pengungkungan yang diimplementasikan pada desain HTGR akan dievaluasi. Hasil evaluasi menunjukkan bahwa desain HTGR dapat mengungkung material radioaktif tetap berada pada sumbernya. Lapisan partikel bahan bakar mampu menahan produk fisi untuk setiap kejadian reaktifitas. Pelepasan material radioaktif tidak akan pernah terjadi meskipun intervensi sistem keselamatan dan operator tidak terlibat dalam aksi pemulihan. Dengan demikian, desain HTGR ini telah memenuhi persyaratan pembangkit nuklir masa depan yaitu tidak diperlukannya evakuasi dan shelter di luar exclusion area boundary.

Kata kunci: Reaktor berpendingin gas temperatur tinggi, fitur keselamatan melekat, fungsi keselamatan fundamental, fungsi pengungkungan, pembangkit nuklir masa depan
\end{abstract}

\section{INTRODUCTION}

High temperature gas cooled reactor (HTGR) design technologies offer advantageous of higher fuel integrity, more resistance to proliferation, and simpler fuel cycle and refueling [1].

* Penulis korespondensi.

E-mail: purba-jh@batan.go.id
HTGR also takes advantages of material properties to improve their safety, namely: (i) ceramic coated and carbon-based fuels to withstand extremely high temperature; (ii) graphite as the materials of the reactor to avoid chemical reaction producing explosive gases; (iii) plant design features to limit air or water ingress; (iv) single phase and low heat capacity of the helium coolant to minimize stored energy; and (v) inherent nuclear and 
heat transfer properties of the reactor design to maintain fuel temperatures within acceptable limits under all conditions.

HTGR has been considered to be the most promising option to meet energy demands in the future [2-4]. It can generate electricity the thermal efficiency of which is higher than light water reactor (LWR) can generate. The practical challenges for nuclear power plants (NPPs) to become energy resources in the future are their safety operations and records. Therefore, safety issues become the most concern for operating and regulating institutions. They have to convince public that the related safety systems can manage and control the release during any accident. Public health and safety also need to be protected from possible radiation hazards during plants' lifetime. Furthermore, the U.S. Department of Energy (DOE) stated that the design of the next generation nuclear plant should be able to limit radioactive material releases to practically eliminate the need for public evacuation or sheltering beyond the exclusion area boundary [5].

HTGR has been categorized as the next generation nuclear plant because of its safety design and reliability [5]. Design philosophy of HTGRs relies on inherent safety features and engineered passive safety features [5, 6]. These features can sufficiently control nuclear power without the need for active safety systems or operator intervention.

Inherent safety features are achieved through TRISO-coated fuel particles, graphite moderator, and helium coolant. Meanwhile, the engineered passive safety features are achieved through the low-power-density core with a relatively large height-to-diameter ratio within an un-insulated steel reactor vessel and large negative temperature coefficient as well as large thermal margin to enable reactor to deal with scram failure.

The purpose of this study is to comprehensively evaluate HTGR designs in order to practically eliminate the need for public evacuation or sheltering beyond the exclusion area boundary. Safety design of HTGR to be reviewed and discussed are inherent safety features, fundamental safety functions, and confinement functions. Evaluations are done using various sources of data and information, such as scientific publications and IAEA publications as well as lecture materials. The HTGR design to be evaluated in this study is HTGR modular, whose power is less than 300 MWth.

\section{METHODOLOGY}

The fundamental objective of the safety measures in nuclear power plants is to protect people and the environment from harmful effects of ionizing radiation. To be selected as the next generation nuclear plant (NGNP), HTGR design needs to be confirmed that public evacuation or sheltering beyond the exclusion area boundary can be practically eliminated.

In this study, three design philosopies of HTGR, i.e. inherent safety features, fundamental safety functions and confinement functions are explored. HTGR inherent safety features include TRISO-coated fuel particles, graphite moderator, and helium coolant. HTGR fundamental safety functions include controlling heat generation, removing heat from the reactor core, and controlling chemical attacks. Meanwhile, HTGR confinement functions include fuel particle kernel, fuel particle coating, core graphite and carbonaceous materials, helium pressure boundary, and reactor building. All collected data and information are, then, evaluated and classified into those three design philosophies to achieve research objectives.

Various sources of available scientific publications are used to collect data and information on HTGR design philosophies.

\section{RESULTS AND DISCUSSION}

The primary safety objective of the next generation nuclear plant is to limit radioactive material releases to practically eliminate the need for public evacuation or sheltering beyond the exclusion area boundary [5]. Three design concepts of HTGR to achieve this primary safety objective are inherent safety features, fundamental safety functions and confinement functions. 


\subsection{HTGR Inherent Safety Features}

To fulfill energy demands in the future, HTGR achieve inherent safety features through the selection and utilization of excellent material properties. HTGR design provision to achieve these inherent safety features are through TRISO-coated fuel particles, graphite moderator, and helium coolant [7].

\subsubsection{TRISO-coated fuel particles}

TRISO-coated fuel particle consists of a fissionable fuel kernel, which is surrounded by four coating layers $[8,9]$. Those four coating layers are porous pyrolytic carbon (PyC) buffer, dense inner pyrolytic carbon (IPyC), chemically vapour deposited silicon carbide ( $\mathrm{SiC})$, and dense outer pyrolytic carbon $(\mathrm{OPyC})$, which are respectively designed from the kernel to the outside of each fuel particle as in Fig. 1. The purpose of those layers is to contain fission products and actinides through the lifetime of the fuel particles [10]. These are key elements in the HTGR design and licensing.

The TRISO-coated fuel particles can withstand temperatures, which are much higher than the metal clad fuels can. They can even withstand extremely high temperatures and retain high radionuclides. They can maintain their abilities to retain radionuclides if the temperature is still at about $1600{ }^{\circ} \mathrm{C}$ [11]. In fact, this temperature will not be exceeded in any accident of HTGRs [12].

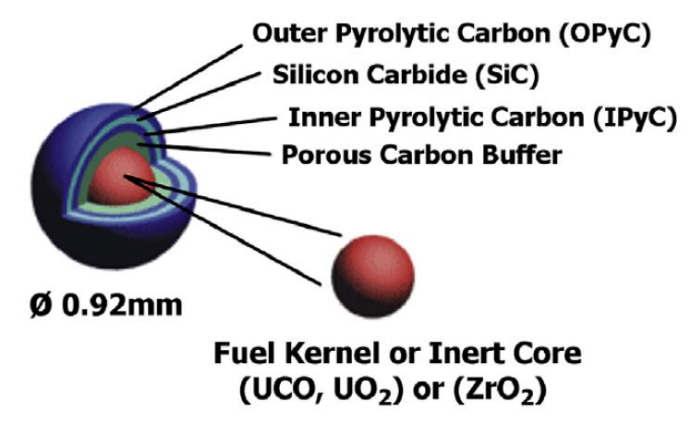

Figure. 1. TRISO-coated fuel particle [13].

Two main factors, which might affect the integrity of TRISO-coated fuel particles are temperature and burn-up [14]. In addition, fuel particle failures can also be affected by irradiation history and manufacturing processes. Fortunately, the failure of one coated fuel particle will not cause neighbouring coated fuel particles to fail such as in LWRs, which can cause significant additional failures. The coated fuel particle failure mechanisms are initiated only by maximum fuel temperature. Even though there are coated fuel particle failures, these failures will not change the heat removal path. This condition will not affect the fuel cool-ability and hence, the integrity of those coated fuel particles are still maintained to retain radionuclides within their sources.

\subsubsection{Graphite moderator}

Graphite moderator complements the extremely high temperature capability of the fuels. It can even withstand temperatures higher than the fuel can without structural damage. Moreover, graphite moderator provides large heat capacity and low power density resulting in temperature transients to be very slow and predictable. Therefore, the peak accident temperatures will be reached within days when the coolant is completely lost. However, this peak temperature is still well below temperatures, which could cause fuel degradation. This condition allows long thermal response times. For example, in loss of forced circulation accident, the fuel peak temperature will only be reached after several days and then slowly decrease [15].

In addition, graphite can retain certain radionuclides to possibly reduce releases from the core. Furthermore, the graphite strength can increase with temperature over the full range of temperatures applicable to the HTGRs.

\subsubsection{Helium coolant}

HTGRs use helium gas, which is pressurized to several megapascals, as the primary system medium for heat transferring. Helium coolant is chemically inert and has high thermal capacity. Furthermore, helium is neutronically transparent and, hence, it will not participate in any chemical or nuclear reaction to aggravate an accident. In addition, helium will not have two-phase flow problem, which could affect reactivity and temperature control such as in LWRs. 
The major concerns for the commercialization of the HTGRs are the primary helium leakage and coolant chemistry during their operations. Tochio et al. [16] confirmed that helium gas is easy to leak, especially at the elevated temperatures and pressures. Therefore, it is necessary to tightly control the possibility of the primary helium leakage to prevent the radioactive material releases into the environment. To minimize the effect of helium leakage if it really happens, a leakage monitoring system is necessary to identify the location of the leakage. Furthermore, helium coolant chemistry also needs to be tightly controlled to prevent graphite and metallic material oxidization. Sakaba, Hamamoto and Takeda [17] found that even though chemical impurity can be removed to as low as possible from helium coolant, it can only maintain core integrity but the mechanical strength and heat transfer efficiency of the high-temperature equipment applied in HTGRs still degrade.

Even though helium leaks out from the primary pressure boundary into the reactor building, it will not condense but will elevate the pressure in a sealed reactor building, which cannot be reduced by cool down. This sustained high-pressure will largely delay the release as fuel temperature increases. This condition is very different from LWRs in the case of loss of coolant accidents. These characteristics can prevent the release of radioactive materials from their sources.

\subsection{HTGR Fundamental Safety Functions}

The integrity of the fuels needs to be maintained to prevent or mitigate radiological consequences to people and the environment in any state and condition. HTGR fundamental safety functions to maintain the integrity of the fuels are by (i) controlling heat generation; (ii) removing heat from the reactor core; and (iii) controlling chemical attacks.

\subsubsection{Controlling heat generation}

Heat generation in HTGRs is controlled by two different systems, i.e. an intrinsic shutdown system and a reliable control material insertion system. The intrinsic shutdown system is performed by a very large core negative temperature coefficient and large thermal margin. In addition, the reliable control material insertion system is realized through two independent and diverse reactivity control systems, i.e. a control rod drop system and a backup or reserve shutdown system, which can fall down by gravity. Each system can maintain subcriticality independently and one of those systems is capable of maintaining cold shutdown during refuelling. These safety systems are designed such as to functionally support active systems, namely: control and protection systems, and reactivity control.

\subsubsection{Removing heat from the reactor core}

Although engineered safety systems do not work, HTGRs is still capable of removing heat from the core due to the large thermal capacity, high thermal conductivity and low power density of the core. Small thermal rating or low core power density can limit the amount of decay heat and provide low linear heat rate. Graphite structure allow high heat capacity and, therefore, to slow the heat up of the graphite core. Moreover, the geometry of the core has been designed to be long, slender and annular cylindrical geometry. It is surrounded by an un-insulated reactor vessel. This design can effectively remove heat through conduction, convection, and radiation. This design also assures sufficient core residual heat removal under loss-of-forced cooling or loss-of-coolant-pressure conditions.

The depressurized loss of forced cooling (DLOFC) is a typical accident in HTGRs, which imposes the strongest requirements for removing heat from the reactor core. Zheng, Y., Shi, L. [18] studied DLOFC and pressurized LOFC (PLOFC) accidents using THERMIX code based on HTR-PM design. They found that, due to passive heat removal capabilities, the maximum temperatures of the fuel element and the reactor pressure vessel (RPV) are still below the design limit with a large safety margin. The passive heat removal capability of HGTRs is graphically shown in Fig. 2 [19]. 


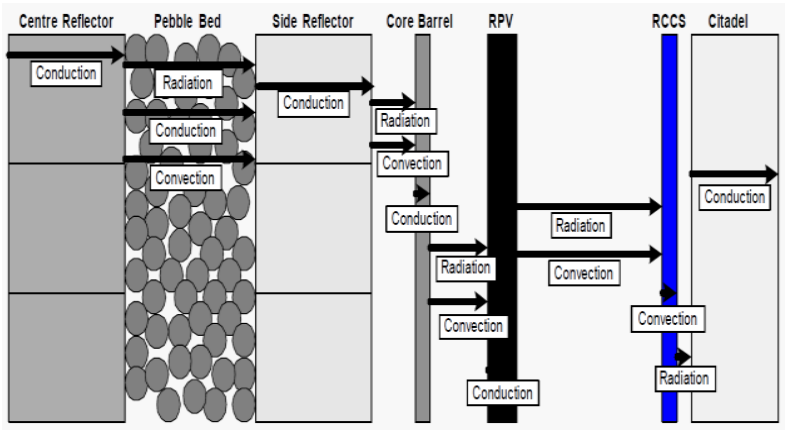

Figure. 2. Passive heat removal capability [19].

The function of the reactor cavity cooling system (RCCS) is to maintain the structure and reactor building concrete temperatures within allowable limit [20]. The RCCS itself is cooled by natural convection of air or water. If RCCS were unavailable, heat from reactor vessel walls would be transferred to the reactor concrete walls through the inoperable RCCS and to the ground surrounding the reactor building. This heat transfer mechanism is still sufficient to retain the maximum temperature of the core to be well below its design limit. Through this mode, vessel creep deformation at the core mid plane is likely to occur after several days [5].

Those passive heat removal systems are designed such as to functionally support two active cooling systems, i.e. main loop cooling system and shutdown cooling system (SCS). When the main loop cooling system is unavailable, the shutdown cooling system is responsible for removing residual heat. This system includes non-safety related small circulator and heat exchanger, which are located at the bottom of the reactor vessel.

\subsubsection{Controlling chemical attacks}

Chemical attacks can challenge the integrity of the fuel particles and graphite core structure by possibly ingressing into the primary system. Two types of chemical attacks, which possibly challenge the integrity of the HTGR fuel particles, are air ingress and water ingress. Air ingress can potentially damage TRISO coated fuel particles and the vessel graphite structures and components through oxidation. Meanwhile, water ingress could cause three major safety concerns, i.e. positive reactivity insertion, graphite corrosion, and potential breach in the radioactivity confinement [21].

Large amounts of air ingress or water ingress accident can be categorized as one of HTGR design extension conditions [22]. During air and/or water ingress accidents, the core temperature is a function of time. Similar to the depressurization accident, the core temperature temporarily decreases due to reactor scram. Due to residual heat, the core temperature will increase after the fuel temperature and graphite block temperature are almost the same. After that condition is reached, the core temperature gradually decreases [23].

Design provisions to limit the effect and amount of air ingress in HTGRs are to slow down oxidation rate. This can be achieved by providing high integrity nuclear grade pressure vessels, limiting core flow area and friction losses, embedding ceramic-coated particles, and venting reactor building. Meanwhile, design provisions to limit the effect and amount of water ingress are to limit source of water. Steam generator isolation, steam generator dump system, endothermic reaction of water-graphite, and graphite coated fuel particle are provided for that purpose [20].

\subsection{HTGR Confinement Functions}

HTGR design provisions for confinement functions are fuel particle kernel, fuel particle coating, core graphite and carbonaceous materials, helium pressure boundary, and reactor building. They work independently in series. If one level of barrier were to fail, the subsequent barrier would be available. The effectiveness of those five barriers to contain radionuclides depends on a number of factors, such as radionuclide chemistry and half-lives, irradiation history, and events challenging the fuels.

\subsubsection{Fuel particle kernel}

The fuel particle kernel is the first barrier to radionuclide release. The main objectives of this kernel are to contain fissile and fertile materials and to retain fission products. It can retain short-lived fission gases such as $\mathrm{Kr}-88$ and I-131 up to a 
substantial fraction of greater than $95 \%$ under normal operating conditions. Unfortunately, its effectiveness to retain fission gasses can be reduced to $80-90 \%$ by elevated temperatures at the peak temperature locations [5]. Fuel particle kernel could be failure to retain gases if the kernel is hydrolysed by water vapour, which might present in the helium coolant. Fortunately, HTGR design provisions have been such as to limit the effect and amount of possible water and/or air ingress as described in Sub-Section 3.2.3.

\subsubsection{Fuel particle coating}

The fuel particle coating is the second and the most important barrier to retain fission gasses within the kernel, particularly in accident conditions. The fuel particle coating with successive layers from the kernel to the outer side are PyC buffer, dense IPyC, chemically vapor deposited $\mathrm{SiC}$, and dense OPyC. The PyC buffer layer is to prevent the damage of coatings from fission fragments and to provide room for generated fission gases. Meanwhile, the dense IPyC layer is to attenuate the migration of fission products and to reduce chemical interaction between fission products and the $\mathrm{SiC}$ layer. The $\mathrm{SiC}$ layer is an excellent barrier for radioactive gases and metallic fission product. It has an excellent high temperature. The $\mathrm{OPyC}$ acts as barrier to fission products. It also chemically and mechanically protects the $\mathrm{SiC}$ layer. In regard to fission product absorption, the buffer layer has a lower density than other three layers [22].

Due to neutron irradiation, Liang et al. [24] found that (1) the buffer layer will experience cracks when the burn-up larger than 40,000 MWd/t; (2) PyC layer will undergo shrinkage to finally develop tensile stress, which can generate compression stress to the $\mathrm{SiC}$ layer; and (3) $\mathrm{SiC}$ layer will experience thermal decomposition at temperatures above $1600{ }^{\circ} \mathrm{C}$. Yang and Allen [25] conclude that $\mathrm{SiC}$ and $\mathrm{PyC}$ coating layers play an important role to provide a barrier to the release of gaseous fission product from the kernel. The integrity of the TRISO layers to retain gases and metallic fission products is still intact for temperatures of approximately $1600{ }^{\circ} \mathrm{C}$.
Above $1700{ }^{\circ} \mathrm{C}$, their mechanical integrities gradually degrade.

Among those four layers, the $\mathrm{SiC}$ layer is the most important layer. The fractures of the $\mathrm{SiC}$ layer are usually perceived as the fracture of the TRISO. The $\mathrm{SiC}$ layer has the greatest strength and irradiation stability [26]. Its functions as a spherical pressure vessel to be the primary barrier for the fission products, which might escape from the kernel and can diffuse through the carbon layers [13]. Since $\mathrm{SiC}$ coating layer will react with air and water under air or water ingress accidents, it is important to improve the resistance of the $\mathrm{SiC}$ layer to the oxidation process [23]. In addition, chemical mechanisms, such as kernel migration, corrosion and decomposition, can also challenge the integrity of the $\mathrm{SiC}$ layer at the temperature over $2000{ }^{\circ} \mathrm{C}$ [14].

\subsubsection{Core graphite and carbonaceous materials}

The implementation of this third barrier depends on the type of the core. For the prismatic core, this third barrier is collectively accomplished by the fuel compact matrix and the fuel block graphite. For the pebble bed core, this third barrier is accomplished by the pebble matrix, which includes the unfuelled outer shell of the spherical pebble fuel element. Reactor materials are chemically compatible and will not react to produce heat or explosive gases. These characteristics can prevent the release of radioactive materials.

Sumita, Shimazaki and Shibata [27] tested the integrity of the core components and graphite core support structures of HTGRs using high temperature Engineering Test Reactor (HTTR). They confirmed that during the high temperature of $950{ }^{\circ} \mathrm{C}$ continuous operations, the structural integrity of the core components and its graphite support structures was still maintained and, therefore, there was no challenge to the core cooling capability.

\subsubsection{Helium pressure boundary}

The helium pressure boundary (HPB) is the forth barrier to contain radioactive releases within the primary system. Once the fission products have been conveyed by 
helium coolant from the core, the helium purification system will efficiently remove gaseous and metallic fission products, which also might be transported from the core, to control chemical impurities in the helium [5].

The high quality of the pressure vessel and limitation of the penetrations can reduce the likelihood of the HPB to break. However, when a break occurs, helium coolant would flow out from the HPB until the pressure of the inside and the outside is equal. In the event of the loss of helium coolant, inherent safety features and passive systems can still maintain the temperature of fuel elements to be well below the temperature where the fuel degradation does not happen. Even in case of the reactor shutdown failure, there is no active emergency core cooling system required to function for the heat removal. Different from LWRs, there is no scenario in HTGRs that can lead to core melt.

\subsubsection{Reactor building}

The reactor building is the last barrier to radionuclide releases to the environment. It surrounds HPB and structurally protects helium pressure vessels and RCCS from external hazards. Its effectiveness to retain radionuclide is highly event specific. In GTHRT300, the leak rate of the reactor building is designed to be less than $5 \% /$ day under $10 \mathrm{~mm} \mathrm{H}_{2} \mathrm{O}$ pressure difference and its design pressure is higher than 1.3 $\mathrm{MPa}$. Due to the airtight closures in the pressure release stack, the reactor building leak rate can be limited to be less than its designed leak rate in the depressurization accident, such as simultaneous break of inner and outer pipes of the coaxial double piping to flow helium gas [28]. To deal with non-condensable helium, which might be contained within the reactor building, it is vented to provide safer design solution.

\section{CONCLUSION}

From the safety points of view, HTGRs have been designed as such to limit the possibility of the radioactive material releases. Inherent safety features to withstand high temperatures have been achieved through TRISO-coated fuel particles, graphite moderator, and helium coolant. Meanwhile, fundamental safety functions to maintain the integrity of the fuel have been achieved by controlling heat generation, removing heat from the reactor core, and controlling chemical attacks. In addition, confinement functions are realized into fuel particle kernel, fuel particle coating, core graphite and carbonaceous materials, helium pressure boundary, and reactor building. This safety provisions have fulfilled the requirement for the next generation nuclear plant, which is to practically eliminated public evacuation or sheltering beyond the exclusion area boundary.

\section{ACKNOWLEDGMENT}

The work presented in this paper was funded by the Ministry of Research, Technology, and Higher Education of the Republic of Indonesia under the FlagshipINSINAS research project of the year 2019 No. 06/INS-1/PPK/E4/2019, which was managed by the Center for Nuclear Reactor Technology and Safety (PTKRN) of National Nuclear Energy Agency of Indonesia (BATAN).

\section{REFERENCES}

1. Kim J.S., Hwang J.-S., Kim E.S., Kim B.J., Oh C.H. Experimental study on fundamental phenomena in HTGR small break air ingress accident. Ann. Nucl. Energy. 2016. 87:145-56.

2. Kim S., Tak N.I., Lim H.S., Ha S.J. Sensitivity study on depressurized LOFC accidents with failure of RCCS in a modular gas-cooled reactor. Ann. Nucl. Energy. 2010. 37:664-71.

3. Ferng Y.M., Chen C.T. CFD investigating thermalhydraulic characteristics and hydrogen generation from graphite-water reaction after SG tube rupture in HTR-10 reactor. Appl. Therm. Eng. 2011. 31(1415):2430-38.

4. Ferng Y.M., Lin K.Y. CFD investigation of thermalhydraulic characteristics in a PBR core using different contact treatments between pebbles. Ann. Nucl. Energy. 2014. 72:156-65.

5. INL Modular HTGR Safety Basis and Approach. Idaho: U.S. Department of Energy, 2011 Contract No.: INL/EXT-11-22708.

6. Vierow K., Hogan K., Metzroth K., Aldemir T. Application of dynamic probabilistic risk assessment techniques for uncertainty quantification in 
generation IV reactors. Prog. Nucl. Energy. 2014. 77:320-28.

7. Sambuu O., Obara T. Comparative study on HTGR designs for passive decay heat removal. Prog. Nucl. Energy. 2015. 82:37-45.

8. Qin W., Yang K., Chen J., Cai X. Dancoff factor analysis for pebble bed fluoride salt cooled high temperature reactor. Prog. Nucl. Energy. 2016. 88:332-39.

9. Morris R.N., Baldwin C.A., Demkowicz P.A., Hunn J.D., Reber E.L. Performance of AGR-1 hightemperature reactor fuel during post-irradiation heating tests. Nucl. Eng. Des. 2016. 306:24-35.

10. Hunn J.D., Baldwin C.A., Gerczak T.J., Montgomery F.C., Morris R.N., Silva C.M., et al. Detection and analysis of particles with failed $\mathrm{SiC}$ in AGR-1 fuel compacts. Nucl. Eng. Des. 2016. 306:36-46.

11. Carlson D.E., Ball S.J. Perspectives on understanding and verifying the safety terrain of modular high temperature gas-cooled reactors. Nucl. Eng. Des. 2016. 306:117-23.

12. Kunitomi K. R\&D on high-temperature gas-cooled reactor technology utilizing Japan's HTTR. J. Nucl. Sci. Tech. 2014. 51(11-12):1315-16.

13. Davis B.C., Ward L., Butt D.P., Fillery B., Reimanis I. Fracture strength and principal stress fields during crush testing of the $\mathrm{SiC}$ layer in TRISO-coated fuel particles. J. Nucl. Mater. 2016. 477:263-72.

14. Jeong H., Jeong Y.H., Chang S.H. Model development for the estimation of fission product release under normal and accident conditions in a HTGR. Nucl. Eng. Des. 2009. 239:1066-75.

15. Reitsma F., Kunitomi K., Ohashi H. The IAEA coordinated research project on modular HTGR safety design: Status and outlook. in: Proceeding International Topical Meeting on High Temperature Reactor Technology. Las Vegas, NV. 2016. pp. 34152.

16. Tochio D., Shimizu A., Hamamoto S., Sakaba N. Helium leak and chemical impurities control technology in HTTR. J. Nucl. Sci. Tech. 2014. 51(11-12):1407-12.

17. Sakaba N., Hamamoto S., Takeda Y. Helium Chemistry for Very High Temperature Reactors. J. Nucl. Sci. Tech. 2010. 47(3):269-77.

18. Zheng Y., Shi L., Dong Y. Thermohydraulic transient studies of the Chinese 200 MWe HTR-PM for loss of forced cooling accidents. Ann. Nucl. Energy. 2009. 36:742-51.

19. Reitsma F. HTGR safety design. in: PowerPoint presentation at the IAEA Course on High temperature Gas Cooled Reactor Technology. Beijing, China. 2012.

20. INL Next Generation Nuclear Plant Probabilistic Risk Assessment White Paper. Idaho: U.S. Department of Energy, 2011 Contract No.: INL/EXT-11-21270.

21. Ball S.J. Overview of Modular HTGR Safety Characterization and Postulated Accident Behavior Licensing Strategy. Oak Ridge, Tennessee: Oak Ridge National Laboratory, 2014 Contract No.: ORNL/TM-2014/187.

22. Aihara J., Ueta S., Honda M., Blynskiy P., Gizatulin S., Sakaba N., et al. Development plan of high burnup fuel for high temperature gas-cooled reactors in future. J. Nucl. Sci. Tech. 2014. 51(1112):1355-63.
23. Ueta S., Sumita J., Shibata T., Aihara J., Fujita I., Ohashi J., et al. R\&D plan for development of oxidation-resistant graphite and investigation of oxidation behavior of $\mathrm{SiC}$ coated fuel particle to enhance safety of HTGR. Nucl. Eng. Des. 2014. 271:309-13.

24. Liang T.X., Zhao H.S., Tang C.H., Verfondern K. Irradiation performance and modeling of HTR-10 coated fuel particles. Nucl. Eng. Des. 2006. 236(18):1922-27.

25. Yang Y.-K., Allen T.R. The measurement of silver diffusivity in zirconium carbide to study the release behavior of $110 \mathrm{mAg}$ in the $\mathrm{ZrC}$ TRISO-coated nuclear fuel particle. J. Nucl. Mater. 2016. 470:7683.

26. Gerczak T.J., Hunn J.D., Lowden R.A., Allen T.R. SiC layer microstructure in AGR-1 and AGR-2 TRISO fuel particles and the influence of its variation on the effective diffusion of key fission products. J. Nucl. Mater. 2016. 480:257-70.

27. Sumita J., Shimazaki Y., Shibata T. Investigation on structural integrity of graphite component during high temperature $950{ }^{\circ} \mathrm{C}$ continuous operation of HTTR. J. Nucl. Sci. Tech. 2014. 51(11-12):1364-72.

28. Katanishi S., Kunitomi K. Safety evaluation on the depressurization accident in the gas turbine high temperature reactor (GTHTR300). Nucl. Eng. Des. 2007. 237:1372-80. 